\title{
Understanding of Construction Product Assessment Issues and Sustainability among Investors, Architects, Contractors, and Sellers of Construction Products in Poland
}

\author{
Jacek Michalak *(D) and Bartosz Michałowski (D) \\ Research and Development Center, Atlas sp. z o.o., 2, Kilinskiego St., 91-421 Lodz, Poland; \\ bmichalowski@atlas.com.pl \\ * Correspondence: jmichalak@atlas.com.pl
}

check for

updates

Citation: Michalak, J.; Michałowski, B. Understanding of Construction Product Assessment Issues and Sustainability among Investors, Architects, Contractors, and Sellers of Construction Products in Poland. Energies 2021, 14, 1941. https:// doi.org/10.3390/en14071941

Academic Editor: Ernest

Effah Ameyaw

Received: 4 March 2021

Accepted: 30 March 2021

Published: 31 March 2021

Publisher's Note: MDPI stays neutral with regard to jurisdictional claims in published maps and institutional affiliations.

Copyright: (c) 2021 by the authors. Licensee MDPI, Basel, Switzerland. This article is an open access article distributed under the terms and conditions of the Creative Commons Attribution (CC BY) license (https:// creativecommons.org/licenses/by/ $4.0 /)$.

\begin{abstract}
The building sector is one of the most critical branches of the economy influencing global warming today. Following the European Union's Construction Products Regulation (CPR), the sustainable use of natural resources in construction is one of the seven basic buildings' requirements. However, due to the lack of provisions in this regard, construction products are not yet subject to mandatory assessment and verification of the constancy of performance in this area. The paper presents the research results with the participation of 842 respondents who are investors, architects, contractors, and sellers of building materials. The analysis of their perceptions of issues related to the term sustainable development and knowledge of selected documents functioning in construction is presented. The share of people who correctly assigned the term sustainable development to equal treatment of environmental protection, economic development, and social development ranged between $52.5 \%$ and $65.7 \%$. Knowledge of people associated with construction about the role of the declaration of performance (DoP) of construction products is high (from $73.9 \%$ to $99.4 \%$ correct answers). For Environmental Product Declaration (EPD), lower knowledge of this document's role was noted, from $24.1 \%$ to $56.5 \%$ of correct answers. The obtained results indicate the need for further education.
\end{abstract}

Keywords: sustainability; construction products; environmental impact; sustainability; assessment of building materials; interdisciplinary research

\section{Introduction}

The current standard of humanity is possible thanks to the exploitation of natural capital on an unprecedented scale. Satisfying the demand of more than 7.8 billion people on Earth is associated with increasing interference with the planet's state [1]. Human activity is one of the most critical factors influencing global warming today. Moreover, each year, the Earth's population increases by 83 million, which means that by the end of 2050, there will be 10 billion of us [2], thus increasing uncertainty about the future of our planet even more.

The concept of sustainable development appeared over thirty years ago to create a new framework for development management [3]. Sustainability refers to the ability to meet the current needs without compromising future generations' need requirements. It stems from the understanding that development focused on maximizing economic and political gains has led to environmental, social, and economic crises. Although the concept of sustainable development integrating the economy, society, and the environment is convincing, it encounters difficulties at disseminating and implementing. Solutions that provide quick economic or political profit and lead to immediate effects are much more often chosen. Politicians, being politically correct, speak of sustainable development, but they primarily mean economic growth, taking into account environmental protection requirements. However, in a situation where it is associated with costs and polls show 
declines in support for political parties, they postpone environmental issues for later [4]. The concept of sustainable development and the related integrated and long-term approach may seem too imprecise. Effective implementation of sustainable development goals requires a change in thinking and a fresh look. For this and other reasons, the United Nations, in 2015, with the votes of all 193 member states, adopted the Agenda for Sustainable Development, including The Sustainable Development Goals (SDGs) in the number of 17 goals and 169 associated targets, related to 5 areas, the so-called 5xP: people, planet, prosperity, peace, and partnership, which the world should adopt by 2030 [5]. The understanding of sustainable development and its implementation faces many obstacles all over the world. Despite the actions taken, the question of the scale and level of knowledge and implementation still seems open. International organizations operate primarily to produce the desired effects globally, but their performance is slow, especially concerning the changes in the climate processes currently taking place.

In the scientific category, the science of sustainable development is interdisciplinary. It is related to economic, technical, and chemical sciences, and environmental protection, with which the shaping of sustainable development is often identified. The selection of the abovementioned scientific disciplines is not a closed set. Science, technology, and innovation have long been recognized as the backbone of socio-economic development and the most crucial factor of sustainable development [6]. Despite the commonly perceived need to conduct research, transdisciplinary projects encounter various difficulties. Therefore, scientists and local stakeholders need to work together to overcome them and create new knowledge to help decision-makers [7]. Moreover, many traditional methods belonging to the scientific apparatus do not work. New actions are necessary, often improvisation. Increasing attention to the tension between process-oriented and descriptive-analytical approaches is observed [8]. The concept of sustainable development is, on the one hand, a scientific category, and on the other, a political one, but the political dimension is dominant. Despite many scientific publications on sustainable development, it is difficult to answer the question: what are the implications and opportunities for legislation of the current state of research?

The construction industry has a huge impact on the economy. In the European Union (EU), the construction sector is of strategic importance, providing 18 million direct jobs and generating 9\% of the EU's gross domestic product (GDP) [9]. The construction sector also has a direct influence on the social aspects of life and the environment. The social dimension is subject to less research than environmental issues and economic aspects [10,11]. The answer to how to measure, evaluate, and certify social sustainability in the construction sector is not yet complete and precise [12].

The construction sector has a significant impact on the economy. The construction sector and building operations also have significant direct and indirect impacts on the environment [13]. In 2019, buildings and construction sectors were responsible for almost $40 \%$ of energy- and process-related emissions [14]. Also, construction materials and buildings generate waste during construction, operation, demolition, and emit potentially harmful substances. More than $30 \%$ of the raw materials extracted in the world and $25 \%$ of the solid waste produced in the world are currently related to construction [15]. The consumption of building materials has tripled in the seventeen years between 2000 and 2017 [16]. Following the implementation of sustainable development principles in the construction industry sector, a significant green building movement appeared, which positively affects the environment $[17,18]$. Growing awareness of the threat of a climate catastrophe and socio-environmental pressure is directing the construction sector's attention towards the re-use of building materials [15,19].

A new economical paradigm, which is a circular economy, has developed in recent years. However, the transition from linear to circular processes does not seem so simple, and much still needs to be done to prove that the circular economy is the concept that will accelerate our transformation towards achieving the assumed sustainable development goals [20]. Considerably, alternative scenarios using sustainable development may be 
implemented when economic growth is not seen as an end in itself. Thus, other goals could be chosen by society to be achieved in the future instead of only economic growth [21].

The issues of assessing construction products and sustainability are essential in various political documents related to the European Union's construction sector [22]. Regulations play a fundamental role in creating reality. A robust legal system in the EU contributes to the national level and legitimizes the theory. Since 1 July 2013, the Construction Products Regulation (CPR) sets out harmonized rules for marketing construction products in the EU [23]. CPR is a base for the free circulation of construction products between member states. Each construction product in the $\mathrm{EU}$ is subject to assessment and verification of constancy of performance (AVCP) under the CPR requirements. The regulation mentioned above states that it is necessary to consider construction works comprehensively, i.e., while taking into account all the basic requirements:

1. Mechanical resistance and stability,

2. Safety in case of fire,

3. Hygiene, health, and the environment,

4. Safety and accessibility in use,

5. Protection against noise,

6. Energy economy and heat retention,

7. Sustainable use of natural resources [23].

The basic requirements listed above from 1 to 6 are commonly used for AVCP of construction products before they are laid down on the market. The seventh basic requirement of sustainable development is still missing from the current mandatory requirements. So far, construction products are not subject to obligatory environmental impact assessment. In line with the CPR, the requirement for the sustainable use of natural resources states that construction works must be designed, constructed, and dismantled in such a way that the use of natural resources is sustainable and ensures, in particular:

- Reuse or recycling of construction works, their materials, and parts after demolition,

- The durability of the construction works,

- The use of environmentally compatible raw and secondary materials in the construction works [23].

Manufacturers assess and verify the constancy of performance (AVCP) of the construction product concerning its essential characteristics following the relevant technical specification (harmonized European standard within the meaning of CPR or a voluntary European Technical Assessment issued at the manufacturer's request). Following the conducted $\mathrm{AVCP}$, manufacturers draw up a declaration of performance (DoP) and affix the CE marking to the product. The construction product's essential characteristics refer to the basic requirements for construction works in Annex I to the CPR. Although, already, in 2004, the European Commission issued M/350 EN Standardization Mandate to CEN to develop horizontal standardized methods for assessing buildings' integrated environmental performance [24], the seventh basic requirement is not a part of the AVCP. Documents constituting the basis of AVCP (European harmonized standard or European Technical Assessment) do not contain the seventh basic requirement. In 2011, European Standard EN 15978 [25] for assessing the environmental performance of buildings was published as the result of the work of CEN/TC 350. In 2012, CEN published European Standard EN 15804 [26] to develop environmental product declarations (EPD) of construction products. EPD is based on the life cycle assessment (LCA) method, standardized in the standards ISO 14040 [27] and ISO 14044 [28], used to assess the environmental impacts of buildings during production, construction, use-also including repair and replacement, and end of life. EPD complies with the standard ISO 14025 [29]. According to the European Commission's policy, EPD's (also known as type III environmental declarations) are valuable tools for sustainable development principles' implementation. In their assumption, these documents should provide transparent, reliable, quantified, and comparable information on products' environmental impact during their life cycle [30,31]. Due to their 
current voluntary nature, they have limited application. Additionally, due to different EPD programs operating according to the same Product Category Rules (PCR), EPDs differ in data quality and specificity, which often causes confusion and leads to misleading comparisons [32-34]. Type III environmental product declarations are used in several multi-criterion certification systems (also voluntary), such as BAMB, BREEAM, CASBEE, DGNB, Green Globes, HQE, LEED, ÖGNI, SBTool, and TQB, and others [35,36]. They are used to a small extent in business-to-business (B2B) communication [37], except for green procurement in some European countries such as Norway, Denmark, and Sweden. Manufacturers of building materials also use data on their products' environmental impact for marketing purposes, preparation of offers for tenders, and fulfilling customers requirements [38]. Manufacturers themselves have a vested interest in recording and assessing the environmental impact of their products. Knowledge in this area allows them to improve their production and purchasing processes continuously [39]. In light of the above, it is evident that further research is needed on the communication formats of EPD to reach various stakeholders effectively [40]. At the start of January 2021, there were over 10,000 verified EPDs under EN 15804 registered globally [41]. It means that the number of registered verified EPDs increased by 2700 during the year 2020. France issued the highest number of EPDs-3101 (FDES (The Framework for the Development of Environmental Statistics) -2651, plus PEPecopassport (PEP ecopassport program) - 450). The second place in the classification is taken by the USA (UL Environment) with 1574, and Germany is third, with 1465 (IBU (Institut Bauen un Umwelt) - 1271, plus IFT(Institut für Fenstertechnik) Rosenheim-194). Poland, with 119 EDPs verified by ITB (Research Building Institute), ranks twelfth in the classification [41]. Since 2011, the European Commission, parallel to the methodology resulting from EN 15804, proposes two other methods to measure environmental performance-Product Environmental Footprint (PEF) and Organization Environmental Footprint (OEF). PEF and OEF apply to the construction. Between 2013 and 2018, 280 volunteering companies took part in the pilot project [42], which resulted in a new Circular Economic Action Plan for a Cleaner and More Competitive Europe [43], one of the European Green Deal [44] blocks. Comparison of results obtained using EPDs and PEFs showed that it is impossible to alternate using both methods [45].

The implementation of sustainable development thinking at the system level for the construction sector is crucial [46]. Holistic thinking about construction, taking into account the seventh basic requirement following CPR at all stages of the construction process, is necessary. The key to achieving the goal in any venture is aware, adequately trained, and committed participants. An appropriate level of knowledge and awareness in the field of broadly understood sustainable development in building materials will allow, through proper decisions, to reduce their negative impact on the natural environment. It is also essential to transparently communicate the research results on buildings/construction materials' environmental impact in prestigious international journals [47]. This paper describes and analyzes the results of knowledge research on selected issues of assessment of construction products and sustainability among investors, architects, contractors, and sellers of construction products. The first three professional groups have a significant impact on the choice of building materials used. The influence of the last of the abovementioned professional groups - sellers of construction products-is smaller. Still, their environmental awareness also influences the market's shape or may affect the final decisionmaking process.

\section{Materials and Methods}

This research, aimed at assessing the perception of issues related to the assessment of construction products, including sustainable development, was carried out in SeptemberOctober 2020 among investors, architects, contractors, and sellers of construction materials. The choice of those four professional groups results from the construction process' specificity and the construction market. According to the provisions of the construction law in Poland, the participants of the construction process are: 
- The investor,

- The investor's supervision inspector,

- Designer/architect,

- Construction manager/construction works manager [48].

Under the provisions of the construction law, some construction sites require an investor's supervision inspector's appointment. Still, in the case of most construction sites, the investor is not obliged to act as an investor's supervision inspector on the construction site, although he can, of course, do so. For this reason, the research did not take into account the professional group of investor supervision inspectors. The seller of building materials, who supplies contractors with the necessary building materials, is an essential link in the construction process. An experienced seller of construction products is a crucial advisor in the construction organization process, facilitating the construction process. Thus, the study was conducted for four professional groups: investors, architects, contractors, and sellers of construction materials.

In the conducted research, the use of the non-random sampling technique was, on the one hand, the only possibility of completing the investigation, but also a chance for its success. The studied samples were selected using one of the non-probabilistic selection techniques - purposive sampling (arbitrary, discretionary, selective)—which is the most typical case of non-random selection [49]. The described study used the existing databases of investors, architects, contractors, and sellers of construction products belonging to the producer of building materials whose research center carried out this project. All these groups of professionals cooperate daily with a manufacturer of building materials. Despite the purposive sampling of the surveyed representatives among professional groups of investors, architects, contractors, and sellers of construction products, it was a choice that ensured valuable information.

Investors' database counts 479 various companies, i.e., developers building single and multi-family residential houses, housing cooperatives, investors of public utility buildings, and industrial facilities investors. When making the selection, three aspects were taken into account. The sample should include representatives of all the types of investors mentioned above. They represent investments of various sizes and come from different regions of Poland, both from large agglomerations and small urban-rural centers. The contractor's database consisted of 9369 items. In 2019, the largest contractor purchased construction materials offered by the manufacturer of building materials conducting the study for about 200,000 euros, and the smallest for about 1000 euros. When making the selection in this group, efforts were made to ensure that contractors of various sizes were evenly represented in the sample, due to the volume of purchased building materials. The second criterium was company location-different regions of the country (both large cities and smaller towns). The sellers of construction products database consisted of 280 companies, the largest of which in 2019 purchased its products for approximately 14 million euro from a construction materials manufacturer that conducts research, and the smallest for roughly 5000 euro. When defining the research sample for this group, two criteria were taken into account: the volume of purchased building materials and the geographical location (all country regions with different urbanization levels). The smallest was the architects' database, with only 45 architectural offices constantly cooperating with the manufacturer of building materials conducting the study. Such a small database of architects/designers concerning the other surveyed groups of professionals may come as a surprise. However, its size resulted, above all, from the type of building materials offered by the manufacturer of building materials, i.e., adhesives for ceramic tiles, grouts, floor-screeds and underlays, plasters, paints, primers, and external thermal insulation composite systems (ETICS). In the case of architects, their selection was based on their geographical location. Also, the town's size of the architectural office was taken into account. 
The sample sizes of each of the surveyed professional groups were calculated according to the Formula (1):

$$
n_{0}=\frac{\frac{z^{2} \times p(1-p)}{e^{2}}}{1+\left(\frac{z^{2} \times p(1-p)}{e^{2} N}\right)}
$$

where: $n_{0}$ is the sample size, $z$ is the selected critical value of desired confidence level, $p$ is the estimated proportion of an attribute present in the population, $e$ is the desired level of precision, and $N$ is the population size.

According to Cochran's assumption, when the population is finite and refers to a small population, the sample size may be slightly reduced [50]. In the modification of Cochran's formula for a smaller population, the sample size is calculated according to the Formula (2):

$$
n=\frac{n_{0}}{1+\frac{\left(n_{0}-1\right)}{N}}
$$

where: $n$ is the final sample size for a small population, $n_{0}$ is the sample size derived from Equation (1), and $N$ is the population size.

Table 1 summarizes the size of the database for each of the surveyed professional groups, the sample size calculated for the desired confidence level of $95 \%$ and $\pm 5 \%$ desired level of precision (margin of error), and the final sample size calculated using the Cochran's formula for the small population. In the final sample size calculated for the small population, the confidence level was equal to $95 \%$ and $\pm 5 \%$ level of precision. The last column of Table 1 shows the actual number of participants that participated in the study.

Table 1. Population size, the sample size for finite population, the sample size for the small population, and real sample size divided into the researched professional groups.

\begin{tabular}{ccccc}
\hline $\begin{array}{c}\text { Professional } \\
\text { Group }\end{array}$ & $\begin{array}{c}\text { Population Size, } \\
\boldsymbol{N}\end{array}$ & $\begin{array}{c}\text { Sample Size } \\
\text { Formula (1), } \boldsymbol{n}_{\mathbf{0}}\end{array}$ & $\begin{array}{c}\text { Sample Size } \\
\text { Formula (2), } \boldsymbol{n}\end{array}$ & $\begin{array}{c}\text { Real Sample } \\
\text { Size }\end{array}$ \\
\hline Investors & 479 & 213 & 147 & 181 \\
Architects & 45 & 40 & 22 & 23 \\
Constructors & 9369 & 369 & 355 & 522 \\
Sellers & 280 & 162 & 102 & 116 \\
\hline \multicolumn{7}{c}{ Total } \\
\hline
\end{tabular}

The survey was conducted in the form of a questionnaire interview, i.e., the interviewer asked questions based on a specially prepared questionnaire. Thus, it was fully structured - the interviewer asked only questions from the questionnaire in a fixed order. The questionnaire's questions were closed, i.e., they had a finite number of precisely formulated answers to choose from in the questionnaire. The choice in some of the questions was a single choice, and some of it was multiple. As stated in Table 1, the research covered 842 respondents, including 181 investors, 23 architects, 522 contractors, and 116 sellers of construction products all over Poland.

Before starting the survey, the interviewer informed the respondent why she or he is taking part in the study. The interviewer also announced what other people/professional groups are participating in the survey and provided information about the survey's nature and scope. The respondent was informed how the organizers of the study would use her/his answers. Additionally, a cover letter was provided to the study participants, drawing attention to the fact that climate change and environmental degradation pose a threat to the whole world and that there is an urgent need to stop the rapidly progressing degradation of the natural environment. The letter noted that the construction industry consumes enormous amounts of natural resources, generating significant construction and demolition waste. Through the appropriate selection of building materials, it can reduce the negative impact on the environment. The information that the interviewer knew the participant in the study is also important for the task. The survey was conducted by 
technical and sales representatives of the manufacturer of building materials cooperating with the study participants, in many cases for many years.

\section{Results}

The survey was conducted during personal visits by technical and commercial representatives of the manufacturer of building materials. The non-respondent rate for all questions in all surveyed professional groups was equal to zero (all survey respondents answered all questions). The results of the survey are summarized in Table 2.

Table 2. Obtained survey results (questions and answers) in the questionnaire in individual surveyed professional groups.

\begin{tabular}{|c|c|c|c|c|c|}
\hline No. & Question & $\begin{array}{c}\text { Investors } \\
(181)\end{array}$ & $\begin{array}{l}\text { Architects } \\
\text { (23) }\end{array}$ & $\begin{array}{c}\text { Contractors } \\
(522)\end{array}$ & $\begin{array}{c}\text { Sellers } \\
\text { (116) }\end{array}$ \\
\hline 1. & $\begin{array}{l}\text { Sustainable development, understood as a management } \\
\text { method for the present generation's needs, will not } \\
\text { reduce the chances of meeting future generations' } \\
\text { needs covers } \\
\text { the following pillar: } \\
\text { (a) environmental } \\
\text { (b) environmental + economic } \\
\text { (c) environmental + social } \\
\text { (d) environmental + economic + social? }\end{array}$ & $\begin{array}{c}28 \\
21 \\
13 \\
119\end{array}$ & $\begin{array}{c}5 \\
6 \\
0 \\
12\end{array}$ & $\begin{array}{l}53 \\
82 \\
46 \\
341\end{array}$ & $\begin{array}{l}20 \\
15 \\
12 \\
69\end{array}$ \\
\hline 2. & $\begin{array}{l}\text { What document is the Declaration of Performance of a } \\
\text { construction product in the EU system with } \\
\text { CE marking: } \\
\text { (a) mandatory } \\
\text { (b) voluntary? }\end{array}$ & $\begin{array}{c}180 \\
1\end{array}$ & $\begin{array}{c}17 \\
6\end{array}$ & $\begin{array}{c}471 \\
51\end{array}$ & $\begin{array}{c}105 \\
11\end{array}$ \\
\hline 3. & $\begin{array}{l}\text { What document is the Environmental } \\
\text { Product Declaration } \\
\text { in the EU system with CE marking: } \\
\text { (a) mandatory } \\
\text { (b) voluntary? }\end{array}$ & $\begin{array}{c}134 \\
47\end{array}$ & $\begin{array}{l}10 \\
13\end{array}$ & $\begin{array}{l}337 \\
185\end{array}$ & $\begin{array}{l}88 \\
28\end{array}$ \\
\hline 4. & $\begin{array}{l}\text { Are you considering the environmental impact when } \\
\text { selecting building materials: } \\
\text { (a) yes } \\
\text { (b) no? }\end{array}$ & $\begin{array}{c}108 \\
73\end{array}$ & $\begin{array}{c}9 \\
14\end{array}$ & $\begin{array}{l}236 \\
286\end{array}$ & $\begin{array}{l}68 \\
48\end{array}$ \\
\hline
\end{tabular}

Which of the following factors:

(b) technical parameters

(b) application parameters

(c) price

(d) environmental impact

is the most important criterion when choosing $\quad 10 \quad 13 \quad 2 \quad 10$ a building material? *

${ }^{*}$ In the case of this question, the table only shows how many respondents indicated environmental impact as the building material selection criterion. The remaining answers were divided between responses-technical parameters, application parameters, and price-but these issues are not considered in this work.

As mentioned previously, each surveyed group's sample size was calculated with a confidence level of $95 \%$ and $\pm 5 \%$ precision level. More respondents in all surveyed professional groups participated in the study than the required number calculated using Cochran's formula for the small population. In the case of architects, one office more (23) than the required 22 architectural offices participated in the study. In the group of sellers of construction products, the study involved more than 14 sales companies (116 versus 102). In the group of investors, by 34 (181 versus 147), and the contractors by as much as 167 (522 versus 355). More respondents than required by Cochran's formula for the small population means that the obtained results are with a higher confidence level or a lower precision level. For example, the participation of 522 contractors means that the survey 
results are characterized by a confidence level of $95 \%$ and $\pm 4 \%$ precision level. However, the architects' sample size determines that all the obtained results are analyzed with a 5\% precision level and a confidence level of $95 \%$.

\section{Discussion}

The first question concerned sustainable development, understood as a method of management for the needs of the present generation, which will not reduce the chances of meeting future generations' needs. They concerned the pillars that sustainability covers and there were four options to choose from: (1) environmental, (2) environmental + economic, (3) environmental + social, and (4) environmental + economic + social. The obtained results are shown in Table 1, and for better illustration, presented in Figure 1.

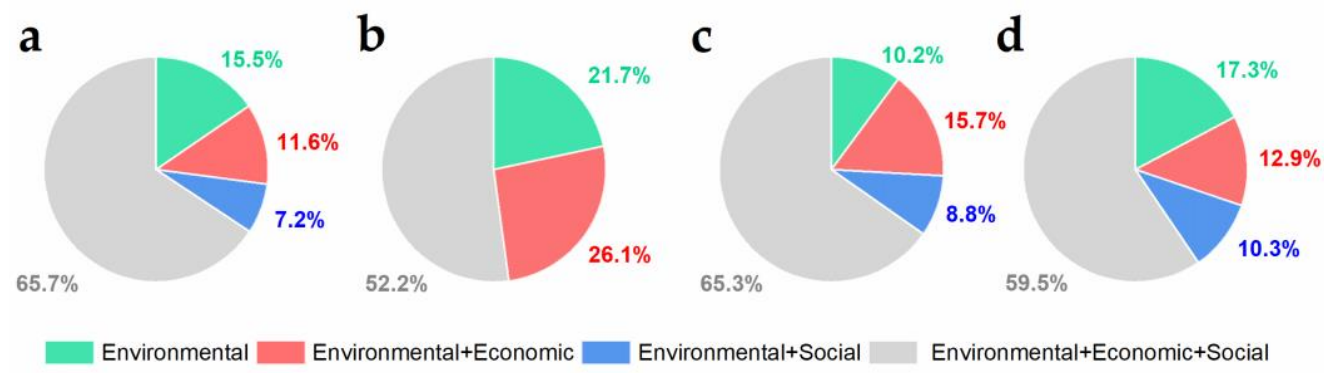

Figure 1. Share of individual answers to the surveyed groups: (a) investors, (b) architects, (c) contractors, (d) sellers of construction products.

Among the surveyed groups, the largest share of people who correctly assigned the term sustainable development to equal treatment of environmental protection, economic development, and social development was recorded among investors and contractors for construction works. Only slightly more than half of architects (52.5\%) correctly associated the term sustainable development. When it comes to sellers of building materials, three out of five had the correct understanding of the term sustainability. Every fifth architect (21.7\%) identified sustainable development only with the environmental dimension. Also, in the remaining three surveyed professional groups, the term sustainable development's association only with the environmental dimension (environmental protection) is significant (from $10.2 \%$ to $17.3 \%$ ). Every fourth architect $(26.1 \%$ ) assigned environmental protection and economic development as components of sustainable development. In the remaining surveyed professional groups, there was a smaller share of those claiming that the environmental and economic dimensions contribute to sustainable development, i.e., $15.7 \%$ for contractors of construction works, $12.9 \%$ for sellers of building materials, and $11.6 \%$ for the group of investors, while $7.2 \%$ of the surveyed investors, $8.8 \%$ of construction contractors, and $10.3 \%$ of building materials sellers understand the term sustainable development as a combination of environmental protection and social development. No architect participating in the study indicated that sustainable development has two pillars-environment and society. In all surveyed professional groups, the submission of environmental and social pillars was less frequent than the environmental and economic pillars, which is generally consistent with the fact that the social dimension of sustainability is subject to less research than economic aspects $[10,11]$.

Research on the issue of social perception of the concept of sustainability conducted in Poland in 2009 showed that only a third of respondents (33.0\%) correctly assigned the term sustainability to equal treatment of economic development, social development, and environmental protection [51]. Research conducted over a decade ago showed the image of Polish society-Poles have relatively limited knowledge of the concept of sustainable development (33\%); despite this, the vast majority (about 70\%) shares its idea and accepts [52].

Taking into account the complexity and the unquestionable need to implement the principles of sustainable development in Poland, an attempt was made to assess how highly 
diversified the space in Poland is in terms of the level of sustainable development and what changes took place in the period 2004-2014 in terms of the level of growth in the area of economy, environment, and society [53]. The analysis was carried out in spatial terms at the level of the regions of the country. The estimated value of the synthetic indicator (own measure proposed by the authors of the work) of the sustainable development level in Poland in the regional system was assessed as low-the reference range of the synthetic indicator could range from zero to one. In contrast, the obtained average values did not exceed the level of 0.4151 in 2004 and 0.4505 in 2014 [53]. Considering that the indicator only changed by $8.5 \%$ over ten years, this may prove, among other things, the need to change the strategy of operation or indicate the need to intensify activities.

Assessment of the state of knowledge and learning about social opinions and attitudes towards the idea of sustainable development, with particular emphasis on farmers, was the subject of research in the period from February 2016 to February 2017. The central premise for undertaking this research task was the statement that the concept of sustainable development was formed on unclear theoretical foundations for an average citizen, which may result in a societal lack of understanding or a misunderstanding of the definition, basic assumptions, and recipients of the concept of sustainable development. Based on the obtained results, a statement was formulated that this concept does not accompany people in everyday life, which was confirmed by $60 \%$ of respondents who met it only occasionally or not at all [54]. The presented selected results of the other studies concerning international research on the opinions and attitudes of academic youth towards the idea of sustainable development carried out in 2017 showed that, compared to other comparative groups, the responses of young Poles showed a passive attitude and ignorance of the principles of sustainable development. On the other hand, the positive fact was that along with increasing the level of education, there is a tendency to raise awareness of sustainable development [55].

Poles' environmental awareness and behavior are, of course, the subject of many studies, including monitoring the implementation of the SDG goals. However, apart from the issues mentioned above, the term sustainable development was not perceived as an equal composition of environmental protection, economic development, and social development. The results described in this paper obtained in assigning individual pillars to the term sustainability indicate significant progress made over the last decade in Poland. One can risk a claim that the construction sector is essential in the development of sustainable development. When analyzing the assignment of the three pillars (environment, economy, and society) to the concept of sustainable development, it is worth mentioning that there are views that such perception is gradually becoming an obstacle [56]. Due to the complexity of sustainability issues, more sophisticated systems and descriptions are needed [56].

The respondents were also asked whether the declaration of performance (DoP) of a construction product is a document that the manufacturer is obliged to issue when laying down a construction product on the market or a voluntary document. The question was: what document is the DoP of a construction product in the EU system with CE marking? There were two answers: (1) mandatory, (2) voluntary. Figure 2 shows the results of the research for each surveyed group.

The manufacturer is obliged to draw up a DoP for construction products covered by harmonized European standards or conform to a European Technical Assessment when the product is placed on the market [23].

In the EU system, the manufacturer assesses and verifies the constancy of performance (ACVP). One of this process' elements is the issuance of a DoP by the manufacturer using the specified declaration model [57] and affixing the CE marking to the product. 

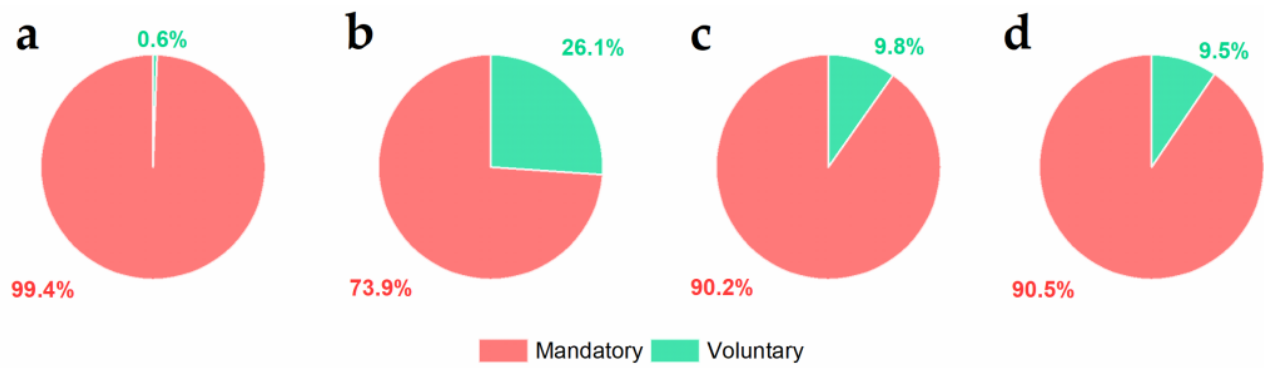

Figure 2. Share of individual answers to the surveyed groups on the Declaration of Performance: (a) investors, (b) architects, (c) contractors, (d) sellers of construction products.

180 out of 181 surveyed investors correctly answered whether the DoP is a mandatory or voluntary document. Nine out of ten sellers of building materials and contractors of construction works responded to this question correctly. The lowest awareness of a form is a DoP was observed among architects, where only $73.9 \%$ of respondents answered the question correctly. Although over $90 \%$ of contractors and sellers of building materials answered correctly, this result can be considered unsatisfactory due to market surveillance authorities' activities. According to Regulation (EC) No 765/2008 [58], each Member State has to establish market surveillance authorities to ensure compliance with this Regulation requirement in their countries. Commonly conducted inspections of construction products include various tasks, including analysis of documentation, including a detailed DoP analysis and control tests of products, which are performed at the request of construction supervision in notified laboratories. Whenever it is found that the product does not meet the requirements, i.e., it does not meet the declared performance, it is necessary to immediately adapt it to the declared performance or withdraw the product from the market immediately. Tests of construction products, performed commonly at Polish construction supervision authorities' request, are not standard in the EU countries. Therefore, the Polish market of construction materials is fundamentally different in this respect $[59,60]$. Taking into account the massive scale of inspections, especially with the participation of contractors and sellers of construction materials, one would expect, in this case, one hundred percent correct answers. However, a little over ninety percent correctness of the answers should be assessed positively.

The next question of the study concerned type III environmental declarations of construction products. Respondents were asked whether the EPD is a mandatory or a voluntary document. The respondents could choose one of two answers: (1) mandatory, (2) voluntary (Figure 3).
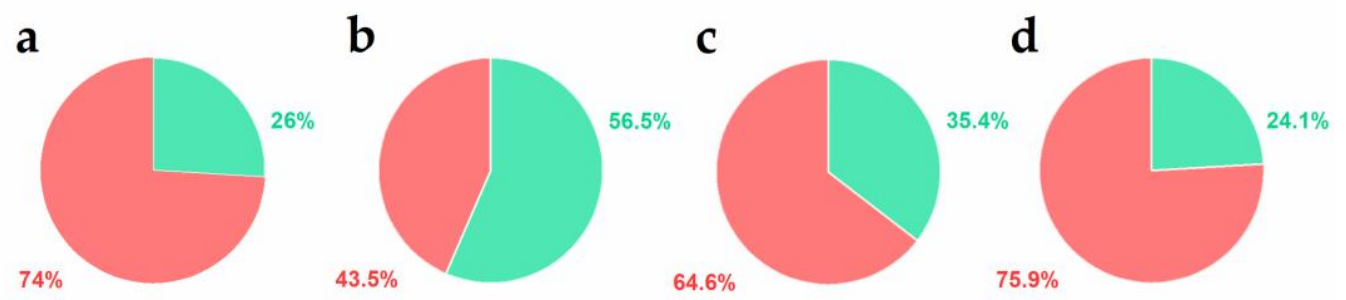

Mandatory $\quad$ Voluntary

Figure 3. Share of individual answers to the surveyed groups on the Environmental Product Declaration: (a) investors, (b) architects, (c) contractors, (d) sellers of construction products.

Figure 3 shows the results for individual surveyed professional groups. The EPD, which is a voluntary document, according to the majority of survey respondents, is a mandatory document. It was stated by 569 study participants, while only 273 correctly answered that it was a voluntary document. In individual professional groups, the share of correct answers ranged from $24.1 \%$ (sellers of construction products) to $56.5 \%$ (architects). 
It is worth noting that the attitudes of designers/architects regarding the use of LCA methods in designing have been rarely analyzed. In 2019, a global survey of designers in 23 countries was conducted to examine the level of awareness and acceptance of environmental performance assessment and LCA of buildings. This study showed that less than a third of designers currently provide or use LCA services. Additionally, those who fail to do so indicated mainly lack of customer demand as the reason [61]. Other studies on the use of LCA information and EPD conducted in a group of practitioners (researchers, directors, managers, advisors, and consultants associated with different sectors) showed that $76 \%$ use both LCA and EPD information. This information primarily meets customer requirements in environmental management systems and for marketing purposes [37].

The explanation for the slightly surprising results presented in Figure 3 may be the distribution of answers to the next question: when selecting a building material, do you consider the impact of this material on the natural environment? The results obtained for individual professional groups are shown in Figure 4.
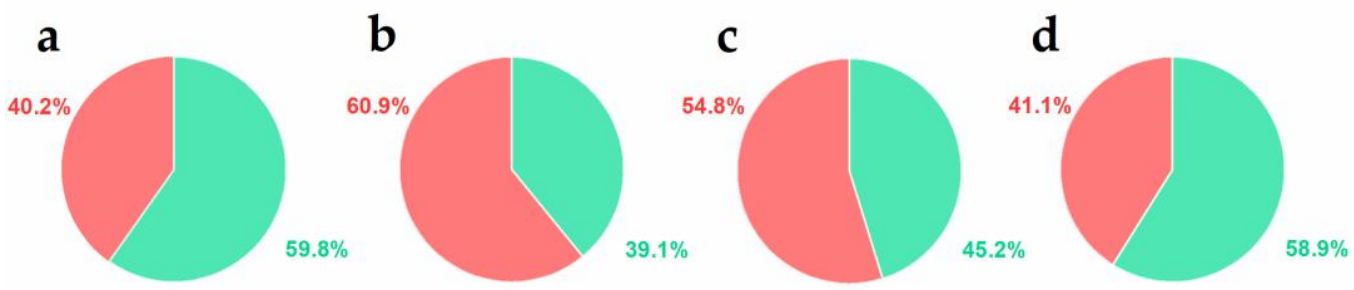

$$
\text { YES NO }
$$

Figure 4. Share of people considering the environmental impact when selecting building materials in the surveyed groups: (a) investors, (b) architects, (c) contractors, (d) sellers of construction products.

Three out of five people in the group of investors and sellers of building materials are guided by environmental impact when choosing a building material. In these two professional groups, most people indicated that the EPDs are mandatory documents.

In the group of architects, the fewest people indicated that EPDs are mandatory documents. In this group, the fewest people told that when choosing a building material, they considered its environmental impact.

Interestingly, when asked to identify the most important factors (technical parameters, application parameters, price, and environmental impact) when choosing a construction product, from $2.5 \%$ (contractors of construction products) to $8.7 \%$ (architects) indicated the most important as environmental impact of a construction product. Figure 5 shows the results for all surveyed professional groups.
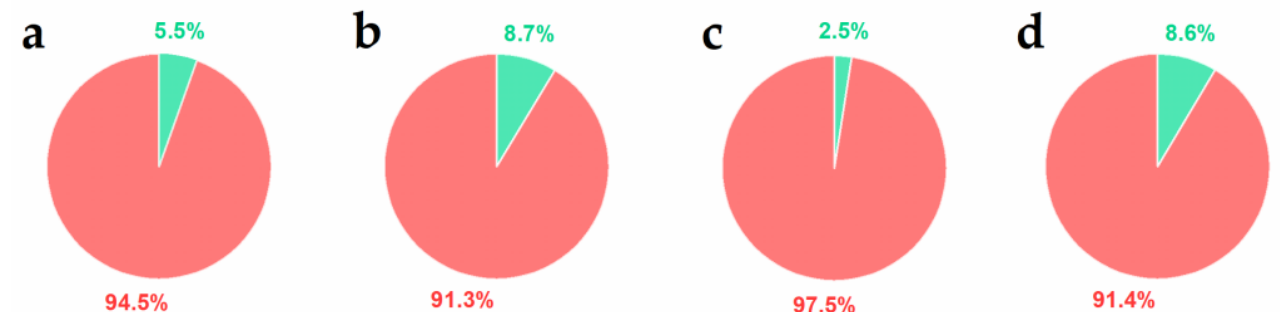

\% of people who indicated environmental impact as the most crucial product choice criteria

Figure 5. Percentage of people who indicated environmental impact as the most crucial criterion out of the four (technical parameters, application parameters, price, environmental impact) when choosing a construction product in the individual surveyed groups: (a) investors, (b) architects, (c) contractors, (d) sellers of construction products.

However, all the groups surveyed in this study are professionals associated with the construction industry. For this reason, when analyzing the results, it should be remembered 
that the studied group is a relatively narrow group of society. It is undoubtedly a limitation of this project. In the case of the last two questions (about consideration of the environmental impact in selecting building materials and an indication of environmental impact as the most crucial criterion during the selection of construction product), the distribution of answers for society may be different.

In the case of questions about the DoP and EPD, i.e., specialistic documents, it can be expected that the knowledge of the surveyed groups is higher than that of the entire society. Because non-probabilistic sampling was used in the study, the obtained results do not reflect Poland's entire community's state of knowledge. When discussing the results obtained for architects, it should be remembered that this research group was the least numerous. The results obtained for all professional groups should be analyzed assuming a confidence level of $95 \%$ and $\pm 5 \%$ precision level.

All surveyed professional groups (investors, architects, contractors of construction work, and sellers of construction materials) play an essential role in reducing buildings' environmental impact by understanding the negative effect of construction products and processes and how to reduce it.

\section{Conclusions}

Although the progressive degradation of the natural environment has been widely discussed for over half a century, and the concept of sustainable development has been present in the public space for over thirty years, its correct perception is not commonly shared. The share of people who correctly assigned the term sustainable development to equal treatment of environmental protection, economic development, and social development, between $52.5 \%$ and $65.7 \%$, should be assessed as high in the presented research. Significantly, if obtained results refer to the research from a decade ago, only one-third of the Poles surveyed could correctly define it. The positive side of the results is that the surveyed professional groups are associated with construction, which significantly impacts sustainable development goals.

A sound signal is also the knowledge of people related to construction about the role of the declaration of performance-a key document in assessing and verifying the constancy of performance of construction products (from 73.9\% to $99.4 \%$ correct answers). It was much worse with the correct indication of the Environmental Product Declaration's role-from $24.1 \%$ to $56.5 \%$ of correct answers. As a positive sign, it should be noted that more respondents (from 39.1\% to 59.8\%) declared considering environmental impact when selecting building materials than the participation of respondents correctly placing EPD in the legal system. On the other hand, however, a tiny number of respondents indicated environmental impact as the most crucial product choice.

The results obtained in the research indicate the need for further educational activities and their intensification. The obtained results correspond well with the recently published study on the Polish transition towards a circular economy [62]. These studies showed that Poles are aware of the need to protect the environment. It is necessary to intensify the population's education on the consequences of excessive environmental exploitation.

The presented research results concern four groups professionally related to construction. For this reason, the obtained results are of limited use. It would be interesting to repeat a similar survey in the future. It would also be interesting to extend the research to more professional groups or the whole of society. In our case, the respondents represented investment, construction, commercial companies, and architectural offices. Therefore, as experts in their professions, they were not identified by other indicators, such as gender or age. Future quantitative studies taking into account gender or age would be interesting. For future studies, the results described in this paper would be a good reference for assessment.

Author Contributions: Conceptualization, formal analysis, investigation, methodology, project administration, supervision, writing — original draft preparation, writing — review and editing, J.M.; formal analysis, investigation, methodology, visualization, writing-review and editing, B.M. All authors have read and agreed to the published version of the manuscript. 
Funding: J.M. was partially supported by the Smart Growth Operational Program 2014-2020 (Project number POIR.02.01.00-00-0350/16).

Institutional Review Board Statement: Not applicable.

Informed Consent Statement: Not applicable.

Data Availability Statement: Not applicable.

Acknowledgments: The authors thank Leszek Pacocha and his team for conducting interviews with respondents and understanding the importance of sustainable development issues.

Conflicts of Interest: The authors declare no conflict of interest.

\section{References}

1. Worldometers. Available online: https://www.worldometers.info/world-population (accessed on 16 January 2021).

2. Jeyanthan, G.; Ilankumaran, G. Circular Economy-Key for the Change of Natural Resource from Scarce to Abundance. Int. J. Recent Technol. Eng. 2019, 8, 666.

3. Brundtland, G. Our Common Future-Call for Action. Environ. Conserv. 1987, 14, 291-294.

4. Hull, Z. The philosophical and social conditioning of sustainable development. Probl. Sustain. Dev. 2008, 3, 27-31.

5. United Nations. Transforming Our World: The 2030 Agenda for Sustainable Development, A/RES/70/1. New York, NY, USA, 2015. Available online: https:/ / www.un.org/ga/search/view_doc.asp?symbol=A/RES/70/1\&Lang=E (accessed on 16 January 2021).

6. Adams, R.; Jeanrenaud, S.; Bessant, J.; Denyer, D.; Overy, P. Sustainability-oriented innovation: A systematic review. Int. J. Manag. Rev. 2016, 18, 180-205.

7. Miller, T.R.; Wiek, A.; Sarewitz, D.; Robinson, J.; Olsson, L.; Kriebel, D.; Loorbach, D. The future of sustainability science: A solutions-oriented research agenda. Sustain. Sci. 2014, 9, 239-246.

8. Wittmayer, J.M.; Schäpke, N. Action, research and participation: Roles of researchers in sustainability transitions. Sustain. Sci. 2014, 9, 483-496. [CrossRef]

9. European Commission, Internal Market, Industry, Entrepreneurship and SMEs. Available online: https://ec.europa.eu/growth/ sectors / construction_en (accessed on 16 January 2021).

10. Abed, A.R. Assessment of social sustainability: A comparative analysis. Proc. Inst. Civ. Eng. Urban Des. Plan. 2017, 170, 72-82. [CrossRef]

11. Murphy, K. The social pillar of sustainable development: A literature review and framework for policy analysis. Sustain. Sci. Pract. Policy 2012, 8, 15-29. [CrossRef]

12. Stender, M.; Walter, A. The role of social sustainability in building assessment. Build. Res. Inf. 2019, 47, 598-610. [CrossRef]

13. Churkina, G.; Organschi, A.; Reyer, C.P.; Ruff, A.; Vinke, K.; Liu, Z.; Reck, B.K.; Graedel, T.E.; Schellnhuber, H.J. Buildings as a global carbon sink. Nat. Sustain. 2020, 3, 269-276.

14. Global Alliance for Buildings and Construction, International Energy Agency and the United Nations Environment Programme. 2019 Global Status Report for Buildings and Construction: Towards a Zero-emission, Efficient and Resilient Buildings and Construction Sector. Available online: https://www.worldgbc.org/news-media/2019-global-status-report-buildings-andconstruction (accessed on 27 December 2020).

15. Benachio, G.L.F.; Freitas, M.D.C.D.; Tavares, S.F. Circular economy in the construction industry: A systematic literature review. J. Clean. Prod. 2020, 260, 121046. [CrossRef]

16. Huang, B.; Gao, X.; Xu, X.; Song, J.; Geng, Y.; Sarkis, J.; Fishman, T.; Kua, H.; Nakatani, J. A Life-Cycle Thinking Framework to Mitigate the Environmental Impact of Building Materials. One Earth 2020, 3, 564-573. [CrossRef]

17. Darko, A.; Chan, A.P. Review of barriers to green building adoption. Sustain. Dev. 2017, 25, 167-179. [CrossRef]

18. Darko, A.; Chan, A.P.; Owusu-Manu, D.G.; Ameyaw, E.E. Drivers for implementing green building technologies: An international survey of experts. J. Clean. Prod. 2017, 145, 386-394. [CrossRef]

19. Van den Berg, M.; Voordijk, H.; Adriaanse, A. Recovering building elements for reuse (or not)-Ethnographic insights into selective demolition practices. J. Clean. Prod. 2020, 256, 120332. [CrossRef]

20. Rodríguez, R.W.; Pomponi, F.; D’Amico, B. Futures studies \& the circular economy: An interdisciplinary approach to sustainable development. Econ. Creat. 2019, 11, 39.

21. Svenfelt, Å.; Alfredsson, E.C.; Bradley, K.; Fauré, E.; Finnveden, G.; Fuehrer, P.; Gunnarsson-Östling, U.; Isaksson, K.; Malmaeus, M.; Malmqvist, T.; et al. Scenarios for sustainable futures beyond GDP growth 2050. Futures 2019, 111, 1-14. [CrossRef]

22. Kylili, A.; Fokaides, P.A. Policy trends for the sustainability assessment of construction materials: A review. Sustain. Cities Soc. 2017, 35, 280-288. [CrossRef]

23. Regulation (EU), No. 305/2011 of the European Parliament and of the Council. Available online: https://eur-lex.europa.eu/ legal-content/EN/TXT/?uri=CELEX:32011R0305 (accessed on 16 January 2021).

24. European Commission. M/350 EN Standardisation Mandate to CEN. Development of Horizontal Standardized Methods for Assessment of the Integrated Environmental Performance of Buildings; European Commission: Brussels, Belgium, 2004. 
25. European Committee for Standardization (CEN). EN 15978:2011 Sustainability of Construction Works-Assessment of Environmental Performance of Buildings-Calculation Method; European Committee for Standardization (CEN): Brussels, Belgium, 2011.

26. European Committee for Standardization (CEN). EN 15804:2012 Sustainability of Construction Works-Environmental Products Declarations-Core Rules for the Product Category of Construction Products; European Committee for Standardization (CEN): Brussels, Belgium, 2012.

27. International Organization for Standardization (ISO). ISO 14040:2006 Environmental Management-Life Cycle Assessment-Principles and Framework; International Organization for Standardization (ISO): Geneva, Switzerland, 2006.

28. International Organization for Standardization (ISO). ISO 14044:2006 Environmental Management-Life Cycle Assessment-Requirements and Guidelines; International Organization for Standardization (ISO): Geneva, Switzerland, 2006.

29. International Organization for Standardization (ISO). ISO 14025:2006 Environmental Labels and Declarations-Type III Environmental Declarations-Principles and Procedure; International Organization for Standardization (ISO): Geneva, Switzerland, 2006.

30. Brinkmann, T.; Metzger, L. Ecological assessment based on environmental product declarations. In Progess in Life Cycle Assessment; Springer: Cham, Switzerland, 2018; pp. 21-31.

31. Bovea, M.D.; Ibáñez-Forés, V.; Agustí-Juan, I. Environmental product declaration (EPD) labeling of construction and building materials. In Eco-Efficient Construction and Building Materials: Life Cycle Assessment (LCA), Eco-Labelling and Case Studies; Woodhead Publishing: New York, NY, USA, 2014; pp. 125-150. ISBN 9780857097675.

32. Anderson, J.; Moncaster, A. Embodied carbon of concrete in buildings, Part 1: Analysis of published EPD. Build. Cities 2020, 1, 198-217. [CrossRef]

33. Waldman, B.; Huang, M.; Simonen, K. Embodied carbon in construction materials: A framework for quantifying data quality in EPDs. Build. Cities 2020, 1, 625-636. [CrossRef]

34. Passer, A.; Lasvaux, S.; Allacker, K.; De Lathauwer, D.; Spirinckx, C.; Wittstock, B.; Kellenberger, D.; Gschösser, F.; Wall, J.; Wallbaum, H. Environmental product declarations entering the building sector: Critical reflections based on 5 to 10 years' experience in different European countries. Int. J. Life Cycle Assess. 2015, 20, 1199-1212. [CrossRef]

35. Bitsiou, E.; Giarma, C. Parameters related to building components' life-cycle analysis in methods for buildings' environmental performance assessment. IOP Conf. Ser. Earth Environ. Sci. 2020, 410, 012066. [CrossRef]

36. Andersen, S.C.; Larsen, H.F.; Raffnsøe, L.; Melvang, C. Environmental product declarations (EPDs) as a competitive parameter within sustainable buildings and building materials. IOP Conf. Ser. Earth Environ. Sci. 2019, 323, 012145. [CrossRef]

37. Galindro, B.M.; Welling, S.; Bey, N.; Olsen, S.I.; Soares, S.R.; Ryding, S.-O. Making use of life cycle assessment and environmental product declarations. A survey with practitioners. J. Ind. Ecol. 2020, 24, 1-11. [CrossRef]

38. Adibi, N.; Mousavi, M. Mainstream Use of EPDs in Buildings: Lessons Learned from Europe. In Proceedings of ISBS 2019 4th International Sustainable Buildings Symposium; Gültekin, A.B., Ed.; IntechOpen: Ankara, Turkey, 2019.

39. Ströbele, B.; Lützkendorf, T. Communicating environmental information: Rethinking options for construction products. Build. Res. Inf. 2019, 47, 681-696. [CrossRef]

40. Welling, S.; Ryding, S.O. Distribution of environmental performance in life cycle assessments-implications for environmental benchmarking. Int. J. Life Cycle Assess. 2021, 1-15.

41. Anderson, J. Construction LCA's 2021 Guide to Environmental Product Declarations. Available online: https:/ /infogram.com/ constructionlcas-2021-guide-to-epd-1h1749vwlxy7l6z?live (accessed on 19 February 2021).

42. European Commission. Single Market for Green Products Initiative. Available online: https://ec.europa.eu/environment/eussd/ smgp/index.htm (accessed on 16 January 2021).

43. European Commission. Communication from the Commission to the European Parliament, the Council, the European Economic and Social Committee and the Committee of the Regions. A New Circular Economy Action Plan for a Cleaner and More Competitive Europe. Brussels, Belgium, 2020. Available online: https://eur-lex.europa.eu/legal-content/EN/TXT/?qid=158393 3814386\&uri=COM:2020:98:FIN (accessed on 16 January 2021).

44. European Commission. The European Green Deal; European Commission: Brussels, Belgium, 2019.

45. Durão, V.; Silvestre, J.D.; Mateus, R.; de Brito, J. Assessment and communication of the environmental performance of construction products in Europe: Comparison between PEF and EN 15804 compliant EPD schemes. Resour. Conserv. Recycl. 2020, 156, 104703. [CrossRef]

46. Sparrevik, M.; de Boer, L.; Michelsen, O.; Skaar, C.; Knudson, H.; Fet, A.M. Circular economy in the construction sector: Advancing environmental performance through systemic and holistic thinking. Environ. Syst. Decis. 2021, 1-9.

47. Pomponi, F.; Crawford, R.; Stephan, A.; Hart, J.; D'Amico, B. The 'building paradox': Research on building-related environmental effects requires global visibility and attention. Emerald Open Res. 2020, 2, 50. [CrossRef]

48. Ustawa o Wyrobach Budowalnych. Available online: http://isap.sejm.gov.pl/isap.nsf/DocDetails.xsp?id=WDU20040920881 (accessed on 12 March 2021).

49. Stamatopoulos, C. A holistic view of finite populations for determining an appropriate sample size. Appl. Sci. Innov. Res. 2019, 3, 219-244. [CrossRef]

50. Cochran, W.G. Sampling Techniques, 3rd ed.; John Wiley \& Sons: New York, NY, USA, 1977.

51. Bałtromiuk, A. Świadomość Ekologiczna Polaków-Zrównoważony Rozwój-Taport z Badań 2009. (In Polish). Institute for Sustainable Development: Warsaw, Poland, 2009; pp. 1-13. Available online: http://odpowiedzialnybiznes.pl/wp-content/ uploads/attachments/news/Swiadomosc_ekologiczna_Polakow_InE_2009.pdf (accessed on 5 February 2021). 
52. Bołtromiuk, A. Polish Society Facing Idea and Principles of Sustainable Development. Probl. Sustain. Dev. 2010, 5, 107-116. [CrossRef]

53. Klonowska-Matynia, M. Regionalne Zróżnicowanie Zrównoważonego Rozwoju w Polsce. Analiza Przestrzenna (in Polish). In Theoria i Praxis Zrównoważonego Rozwoju. 30 lat od Ogłoszenia Raportu Brundtland. Towarzystwo Naukowe Franciszka Salezego: Warsaw, Poland, 2017; pp. 369-382. Available online: https://www.pine.org.pl/wp-content/uploads/2017/08/ theoria_praxis.pdf (accessed on 5 February 2021).

54. Dacko, M.; Plonka, A. Idea rozwoju zrównoważonego w opiniach i postawach rolników (in Polish). Rocz. Nauk. Stowarzyszenia Ekon. Rol. Agrobiz. 2017, 19, 38-43.

55. Dacko, M.; Płonka, A.; Prus, P. Młodzież akademicka względem idei rozwoju zrównoważonego. Rocz. Nauk. Stowarzyszenia Ekon. Rol. Agrobiz. 2018, 20, 24-29.

56. Lützkendorf, T. Assessing the environmental performance of buildings: Trends, lessons and tensions. Build. Res. Inf. 2018, 46, 594-614. [CrossRef]

57. European Commission. Commission Delegated Regulation (EU) no 574/2014 Amending Annex III to Regulation (EU) no 305/2011 of the European Parliament and of the Council on the Model to Be Used for Drawing Up a Declaration of Performance on Construction Products. Brussels, Belgium, 2014. Available online: https:// eur-lex.europa.eu/legal-content/EN/TXT/?uri= celex\%3A32014R0574 (accessed on 5 February 2021).

58. European Commission. Regulation (EC) no 765/2008 of the European Parliament and of the Council Setting Out the Requirements for Accreditation and Market Surveillance Relating to the Marketing of Products and Repealing Regulation (EEC) no $339 / 93$. Brussels, Belgium, 2008. Available online: https:/ / eur-lex.europa.eu/legal-content/EN/TXT/?uri=CELEX:32008R0765 (accessed on 5 February 2021).

59. Łukasik, M.; Michałowski, B.; Michalak, J. Assessment of the Constancy of Performance of Cementitious Adhesives for Ceramic Tiles: Analysis of the Test Results Commissioned by Polish Market Surveillance Authorities. Appl. Sci. 2020, 10, 6561. [CrossRef]

60. Kulesza, M.; Łukasik, M.; Michałowski, B.; Michalak, J. Risk related to the assessment and verification of the constancy of performance of construction products. Analysis of the results of the tests of cementitious adhesives for ceramic tiles commissioned by Polish construction supervision authorities in 2016-2020. Cem. Wapno Beton 2020, 25, 444-456.

61. Balouktsi, M.; Lützkendorf, T.; Röck, M.; Passer, A.; Reisinger, T.; Frischknecht, R. Survey results on acceptance and use of Life Cycle Assessment among designers in world regions: IEA EBC Annex 72. IOP Conf. Ser. Earth Environ. Sci. 2020, 588, 032023. [CrossRef]

62. Tomaszewska, J. Polish Transition towards Circular Economy: Materials Management and Implications for the Construction Sector. Materials 2020, 13, 5228. [CrossRef] 